\title{
Travelling Knowledge and Forensic Medicine: Infanticide, Body and Mind in the Netherlands, $1811-1911$
}

\author{
WILLEMIJN RUBERG* \\ Cultural History, Department of History and Art History, Utrecht University, Drift 6, \\ 3512 BS Utrecht, The Netherlands
}

\begin{abstract}
This article aims to explain why the notion of mania puerperalis, or puerperal insanity, was not used in the Netherlands to exonerate women accused of infanticide, in contrast to other countries. It applies the concept of 'travelling knowledge' as an approach to the history of forensic medicine, pointing to the fields of medicine and law as contact zones inviting, promoting or barring the transmission of knowledge. Although the notion of mania puerperalis was known in the Netherlands from 1822 on, psychiatric expertise was not requested in actual court cases of infanticide for several reasons. First, physicians and legal scholars continued to doubt the existence of this form of mania. Moreover, it was not always directly connected to infanticide. Also, the specific formulation of the law strongly determined what medical evidence was needed in court cases. Not only did the Code Pénal generally emphasise material evidence, the laws on infanticide specifically mentioned fear and therefore an additional reference to the mental condition of the accused was not needed. Most importantly, the article argues that the existing vocabulary on emotion, both vernacular and medical, already allowed for an analysis of psychic components.
\end{abstract}

Keywords: Forensic Medicine, Infanticide, Knowledge, Psychiatry, Emotions

\section{Introduction}

The theme of infanticide ${ }^{1}$ has received increasing attention from historians in recent years. Reasons for this growing interest include curiosity into the daily lives of poor women, and also the sharp contrast between a strong ideology of motherhood and a crime that seems to completely contradict the image of maternity. Scholars have studied the socio-economic backgrounds of these women, their trials and punishments, ${ }^{2}$ as well as the influence of

* Email address for correspondence: W.G.Ruberg@uu.nl

I would like to thank the following scholars for their helpful comments on previous versions of this article: Kristine Steenbergh, Marie Paris, the anonymous reviewers and the audience of the UCLA History of Science, Medicine and Technology Colloquium, where I was kindly allowed to give a paper on this theme on 23 April 2012.

${ }^{1}$ In this article I use the words 'infanticide' and 'child murder' interchangeably, both referring to the murder of newborn babies, although the Dutch laws did not specify the age of the child.

${ }^{2}$ Some of the many important texts include: Mark Jackson (ed.), Infanticide. Historical Perspectives on Child Murder and Concealment, 1550-2000 (Aldershot: Ashgate, 2002); Regina Schulte, Das Dorf im 
Enlightenment humanitarianism, including sympathy for the plight of child murderers, who came to be seen as victims rather than criminals. Particularly, these women's motives, however elusive, have intrigued historians. ${ }^{3}$

Dutch historians have mostly focused on the socio-economic backgrounds of child murderers in the eighteenth, and to a lesser extent, nineteenth century. These studies all indicate that most of the women accused of newborn child murder were unmarried servants who tried to hide their pregnancy and birth out of shame. Fearing the loss of their jobs and livelihood as unmarried mothers, as well as their honour, they resorted to murdering their babies. Similar to research in other countries, Dutch historians have assumed only a limited number of cases of child murder were actually tried before the courts, pointing to an unknown 'dark number'. ${ }^{4}$

Besides the socio-economic background and the presumed motivations of these murdering mothers, historians have studied the Dutch laws on infanticide, including the sentences in practice, which I will elaborate on below. Here, it is relevant to note that Dutch scholars have paid scant attention to the role of forensic medicine and psychiatry in court cases of infanticide, even though doctors were indispensable in cases of infanticide. From the early modern period physicians were called in to examine a dead baby's body, to establish whether it was stillborn or born alive and possibly murdered. Sometimes the bodies of women who were accused of infanticide were searched for signs of recent pregnancy. Physicians vehemently debated the crime of child murder and the weight of

Verhör. Brandstifter, Kindsmörderinnen und Wilderer vor den Schranken des bürgerlichen Gerichts Oberbayern 1848-1910 [The Village Interrogated. Arsonists, Child Murderer and Vagabonds in the Civil Courts of Oberbayern 1848-1910] (Reinbek: Rowolt, 1989); Mark Jackson, New-born Child Murder: Women, Illegitimacy and the Courts in Eighteenth-century England (New York: Manchester University Press, 1996); Brigitte H. Bechtold and Donna Cooper Graves (eds), Killing Infants: Studies in the Worldwide Practice of Infanticide (Lewiston: The Edwin Mellen Press, 2006).

${ }^{3}$ Margaret L. Arnot, 'Understanding women committing newborn child murder in Victorian England', in Shani D'Cruze (ed.), Everyday Violence in Britain, 1850-1950. Gender and Class (Harlow: Pearson Education Limited, 2000), 55-69.

${ }^{4}$ Sjoerd Faber, 'Dienstboden: dieveggen en kindermoordenaressen?' ['Maidservants: Thieves or child murderers?'], in J.W. ter Avest and H. Roozenbeek (eds), Stigmatisering en strafrecht. De juridische positie van minderheden in historisch perspectief [Stigmatisation and Criminal Law. The Judicial Position of Minorities in Historical Perspective] (Leiden: Stichting Leidschrift, 1990), 53-62. Sjoerd Faber, 'Kindermoord, in het bijzonder in de achttiende eeuw te Amsterdam' ['Child Murder, Especially in the Eighteenth Century in Amsterdam'], BMGN, 93, 2 (1978), 224-40; Sjoerd Faber, 'Vrouwen van de rekening. Kindermoordzaken ten tijde van de Republiek te Amsterdam (in het bijzonder in de zeventiende eeuw) en in Friesland' ['Female victims. Cases of child murder in the republic in Amsterdam (especially the seventeenth century) and in Friesland'], in Gert Hekma and Herman Roodenburg (eds), Soete minne en helsche boosheit. Seksuele voorstellingen in Nederland 1300-1850 [Sweet Love and Infernal Anger. Sexual Imagery in the Netherlands 1300-1850] (Nijmegen: SUN, 1988), 145-67; Maria Grever, 'Niet in haar kraam te pas. Kindermoord in het departement Brabant, speciaal in het arrondissement's-Hertogenbosch, 1811-1838' ['Not up her street. Child murder in the province of Brabant, especially in the district of 's-Hertogenbosch, 1811-1838'], in Maria Grever and Annemiek

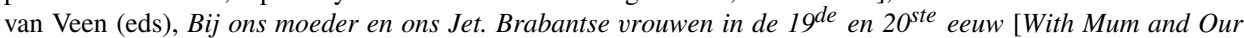
Jet. Brabant Women in the 19th and 20th Centuries], second edn (Zutphen: Walburg Pers, 1989), 13-33; Dirk Jaap Noordam, "“Volgens Goddelijke en menschelijke wetten ten hoogste strafschuldig". Kindermoord voor de rechter in Leiden, 1546-1791' ['According to divine and human laws utterly guilty. Child murder before the courts in Leiden, 1546-1791'], Jaarboek der sociale en economische geschiedenis van Leiden en omstreken [Yearbook of Social and Economic History of Leiden and Surroundings] (2004), 21-43; Greddy Huisman and Siem van der Woude, "Vrouwmensch Vrouwmensch, hoe bistu hier toe gekomen?" Kindermoord in Friesland in de periode 1700-1811' ["Woman, Woman, How Have You Ended up Here?" Child Murder in Friesland in the Period 1700-1811'], De Vrije Fries [The Free Frisian], 68 (1988), 37-62; Jolie Ermers, 'Kindermoord in de negentiende eeuw: en om de vrouw verging het kind' ['Child Murder in the Nineteenth Century: and the Child Passed Away Because of the Woman'], Nemesis, 6, 3 (1990), 114-22. 
their medical findings in these cases, both amongst themselves and with legal scholars. This article explores the influence of forensic doctors and psychiatrists in Dutch court cases of infanticide in the period 1811-1911. In 1811 the French Code Pénal was introduced in the Netherlands and in 1911 the concept of 'puerperal insanity' (insanity during or directly after birth) was used for the first time in court, as part of the question whether Jannetje J., a servant girl, was accountable for her crime. In contrast to England, where reference to puerperal insanity was used as a line of defence since 1822 , in the Netherlands this concept did not play a role in nineteenth and early twentieth century court cases of child murder. In order to account for this absence, first I suggest more attention is paid to the connections between body and mind in contemporary formulations of affect, which provided room to discuss forms of insanity without the need to resort to the new science of psychiatry. Second, I propose a new approach to the history of forensic medicine, emphasising 'travelling knowledge'.

I have adapted the concept of 'travelling knowledge' from insights presented by scholars from different disciplines. ${ }^{5}$ Historians and sociologists of knowledge have already stressed how knowledge is socially constructed and negotiated. ${ }^{6}$ In particular, science and technology studies have demonstrated how knowledge is produced in laboratories and how factual information comes to be seen as such. ${ }^{7}$ The idea of travelling knowledge has mostly been applied to the appropriation of scientific knowledge from other continents in the early modern period. Historians have traced how scientific knowledge has been passed on between people, countries and continents, showing that

the process of travel [...] involves much more than simply moving something from one place to another so that, in the end, it remains the same even if found elsewhere. There is no displacement, whether it be of people, instruments, objects, or data, without some sort of work, material as well as social, which enables their extraction from a given place and context, and insertion in a new place and new set of relations. ${ }^{8}$

Not only in the field of history of science has the mobility of knowledge been emphasised. Cultural theorist Mieke Bal, as well, has introduced the notion of 'travelling concepts' in the humanities, showing how certain concepts travel between academic disciplines, in the meantime changing these disciplines, while also changing themselves. ${ }^{9}$ In a similar vein, literary critic and theorist Stephen Greenblatt recently presented 'a mobility studies manifesto', urging scholars to take seriously the concept of mobility in cultural history. Greenblatt advocates studying mobility in a literal sense, pointing to the 'physical, infrastructural, and institutional conditions of movement', but he also encourages us to

\footnotetext{
${ }^{5}$ See David Turnbull, 'Travelling knowledge. Narratives, assemblage and encounters', in Marie-Noëlle Bourguet et al. (eds), Instruments, Travel and Science. Itineraries of Precision from the Seventeenth to the Twentieth Century (London and New York: Routledge, 2002), 273-94.

${ }^{6}$ Peter Burke, A Social History of Knowledge. From Gutenberg to Diderot (Cambridge: Polity Press, 2000); Pamela H. Smith and Benjamin Schmidt, 'Introduction. Knowledge and its making in early modern Europe', in Pamela H. Smith and Benjamin Schmidt (eds), Making Knowledge in Early Modern Europe. Practices, Objects, and Texts, 1400-1800 (Chicago, IL, and London: The University of Chicago Press, 2007), 1-16.

${ }^{7}$ Bruno Latour, Science in Action: How to Follow Scientists and Engineers through Society (Cambridge, MA: Harvard University Press, 1987); Amâde M'charek, 'Technologies of Population: Forensic DNA Testing Practices and the Making of Differences and Similarities', Configurations, 8 (2000), 121-58. For important historical works, see Steven Shapin, A Social History of Truth. Civility and Science in Seventeenth-century England (Chicago, IL, and London: University of Chicago Press, 1994); Barbara Shapiro, Probability and Certainty in Seventeenth-century England: A Study of the Relationships between Science, Religion, History, Law and Literature (Princeton, NJ: Princeton University Press, 1983).

${ }^{8}$ Marie-Noëlle Bourguet et al., 'Introduction', in Bourguet et al. op. cit. (note 5), 1-19, 5.

${ }^{9}$ Mieke Bal, Travelling Concepts in the Humanities: A Rough Guide (Toronto: University of Toronto Press, 2002).
} 
pay attention to hidden as well as conspicuous movements of peoples, objects, images, texts, and ideas. Importantly, Greenblatt underscores that 'mobility studies should identify and analyse the "contact zones" where cultural goods are exchanged'. ${ }^{10}$

Applying these ideas on cultural mobility to medical history, I propose to trace the way medical knowledge 'travelled' to the courtroom and, on its way, was adapted to the judicial context. From this perspective, the courtroom might be regarded as a 'contact zone' with its own rules of behaviour, shaping the insights from the medical field as doctors and psychiatrists were called in as expert witnesses. These rules might change when the law is reformulated, when medical expertise changes, or when other cultural images or expectations influence the judicial process. In this article, I aim to show how medical knowledge of mania puerperalis, or puerperal insanity, travelled from England and Germany to the Netherlands, but, more importantly, which barriers subsequently prevented this knowledge from being applied in court cases of infanticide. The courtroom might be seen as a contact zone between the medical and judicial fields, both fields stimulating the exchange of knowledge, but also dismissing the appropriation of new ideas.

The concept of 'travelling knowledge' might help the formulation of theoretical approaches to the history of forensic medicine. Although the history of forensic medicine has recently received more attention, the field remains undertheorised. Often, it is presented as the unfolding of better technological knowledge, like the introduction of chemical tests, culminating in the application of DNA, that ultimate 'instrument of truth', in court cases in the 1980s. ${ }^{11}$ However, progressivist histories of medicine have been under scrutiny for some decades, for instance by cultural historians, who underline the social construction of science, medicine and disease. ${ }^{12}$ Social-constructionist approaches have, however, hardly been applied to the history of forensic medicine - some important works excepted. ${ }^{13}$

For instance, in his study of nineteenth-century Norwegian practices of forensic psychiatry, Skålevåg distinguishes between two approaches. The first he designates as the historical sociology of professions, exploring the growing power of medicine and the law as professions, their competition and their pursuit for greater public esteem. The second perspective revolves around a Foucauldian discourse analysis and regards medicine and the law as cooperative, not as competing branches of the medico-legal apparatus in the nineteenth century. In the latter approach, an impersonal scientific discourse, disciplining criminals, is seen to have taken precedence over a specific body of lawyers, judges or doctors. Skålevåg eventually regards both approaches as complementary, but found little evidence for prestige as a strategic professional goal, thereby concluding that the model of professional interest does not carry sufficient analytical potential. Rather than describing the history of forensic psychiatry as a 'medicalization of law', Skålevåg shows how, in Norway, psychiatrists in the nineteenth century also cooperated with the law,

\footnotetext{
${ }^{10}$ Stephen Greenblatt, 'A mobility studies manifesto', in Stephen Greenblatt (ed.), Cultural Mobility. A Manifesto (Cambridge: Cambridge University Press, 2010), 250-3.

11 The recent overview of the history of forensic medicine by Katherine D. Watson, Forensic Medicine in Western Society: A History (New York: Routledge, 2010) is very helpful, but does not pay any attention to theoretical approaches or methodology used by historians of forensic medicine.

12 M.E. Fissell, 'Making meaning from the margins. The new cultural history of medicine', in F. Huisman and J. Harley Warner (eds), Locating Medical History (Baltimore, MD: The Johns Hopkins University Press, 2004), 364-89: 369; Ludmilla Jordanova, 'The Social Construction of Medical Knowledge', Social History of Medicine, 8,3 (1995), 361-8.

13 Carol A.G. Jones, Expert Witnesses. Science, Medicine, and the Practice of Law (Oxford: Clarendon Press, 1994), 2.
} 
and sometimes opposed general medicine. By focusing on broader contemporary cultural conceptions of mankind, he concludes that a separation between body and mind in the course of the nineteenth century opened up a space for psychiatrists to claim expertise on the mind. ${ }^{14}$

Skålevåg has pointed to fruitful approaches to a cultural history of forensic medicine. In addition to his emphasis on the body-mind dichotomy and his focus on shifting alliances between medicine, psychiatry and law, I would like to propose another perspective, that of 'travelling knowledge', to show how knowledge from the field of medicine was transferred to the courts, or, in the case of puerperal insanity, was barred from the legal arena. In order to apply this concept to Dutch court cases of infanticide, I have studied the legal records of all (fifty-seven) cases of infanticide tried before the courts of North-Holland and Amsterdam. ${ }^{15}$ In addition to these records, my sources include textbooks of forensic medicine as well as legal and medical texts on the role of physicians and psychiatrists in cases of child murder. Before I analyse these sources, however, I will sketch the characteristics of Dutch laws on infanticide in the nineteenth century.

\section{Dutch Laws on Infanticide}

In 1774 the Enlightened humanitarian Dutch doctor Petrus Camper advocated leniency for women accused of child murder. ${ }^{16}$ Camper pointed to the stringent social laws on marriage which made unmarried mothers into victims, rather than perpetrators. However, he was also criticised for his views. ${ }^{17}$ In other countries, as well, Enlightened ideas on crime and punishment influenced debates on infanticide. ${ }^{18}$ Thomas Laqueur has shown how humanitarian narrative in its attention to the body 'not only as the locus of pain but also as the common bond between those who suffer and those who would help', fostered compassion and empathy. ${ }^{19}$ Sheena Sommers, applying Laqueur's concept of the humanitarian narrative to eighteenth-century court cases of infanticide, argues that medical expertise of physicians, having replaced the traditional knowledge of midwives, left room for empathy towards the murdering mothers, regardless of - or even because of - its uncertainty. ${ }^{20}$ Mark Jackson critically discusses the contemporary, progressivist cultural

\footnotetext{
${ }^{14}$ Svein Atle Skålevåg, 'The Matter of Forensic Psychiatry: A Historical Enquiry', Medical History, 50, 1 (2006), 49-68.

15 The legal records include interrogation records by the police and notes on the legal procedures. During most of the nineteenth century, severe crimes like murder and child murder were automatically referred to the higher courts at a provincial level; from 1876 the high court of Amsterdam also served as court of appeal. The cases from 1811-38 were tried before the Hof van Assisen, from 1838-41 before the Criminele Rechtbank Holland, from 1842-86 before the Provinciaal Gerechtshof, and from 1887-1911 before the Gerechtshof Amsterdam.

${ }^{16}$ Petrus Camper, Gerechtelyke en ontleedkundige verhandeling over de tekenen van leven, en dood in nieuwgeborene kinderen [Forensic and Anatomical Treatise on the Signs of Life, and Death in New Born Babies] (Leeuwarden: H.A. de Chalmot, 1774), 4-6.

17 S.M.D.V., Het belang der maatschappye in het beteugelen van den kindermoord. Briefsgewyze voorgestelt aan de hooggeleerden en zeer beroemden heere Petrus Camper [The Interest of Society in Curbing Child Murder. Proposed to the Very Learned and Famous Gentleman Petrus Camper, in Letters] (Leeuwarden: H.A. de Chalmot, 1774).

${ }^{18}$ Mary Nagle Wessling, 'Infanticide trials and forensic medicine: Württemberg, 1757-93', in Michael Clark and Catherine Crawford (eds), Legal Medicine in History (Cambridge: Cambridge University Press, 1994), 117-44.

${ }^{19}$ Thomas Laqueur, 'Bodies, details, and the humanitarian narrative', in Lynn Hunt (ed.), The New Cultural History (Berkeley, CA: University of California Press, 1989), 177-9.

${ }^{20}$ Sheena Sommers, 'Remapping maternity in the courtroom. Female defenses and medical witnesses in eighteenth-century infanticide proceedings', in Elizabeth Klaver (ed.), The Body in Medical Culture (Albany, NY: State University of New York Press, 2009), 37-59: 40.
} 
discourse on humanitarianism in relation to crime and punishment. According to Jackson, a new medical discourse and the increasing influence of scientific testimonies in court were more influential in the changing view on crime and punishment. ${ }^{21}$ Humanitarian arguments mostly influenced Dutch legal reform only in the nineteenth century. Moreover, the role of forensic medicine and psychiatry in promoting legal reform was small, especially in comparison with England.

In the eighteenth century the numbers of women prosecuted for infanticide in the Netherlands were relatively low and the verdicts lenient: judges were unwilling to sentence the perpetrators to death. ${ }^{22}$ Although punishment became less severe from the end of the eighteenth century, resulting from increasing sympathy for the plight of unmarried mothers, the death penalty for child murder was not abolished in the Netherlands until 1854. In 1811 the Dutch adopted the French Code Pénal, which penalised infanticide with the death penalty, leading to a high number of acquittals since the 'materialist' French law hardly allowed for extenuating circumstances and the death penalty was seen as too severe by many people. ${ }^{23}$ Between 1811 and 1870 about fifty death sentences were proclaimed for child murder in the Netherlands, but most of the convicts received pardon from the king and were subsequently given prison sentences of fifteen to twenty years. ${ }^{24}$ Generally, acquittal on the basis of insanity was possible, but partial non-responsibility did not exist, probably explaining why, until the late nineteenth century, few medical doctors were called on to establish the sanity of the accused in Dutch courts of law. ${ }^{25}$ The Code Pénal, used in the Netherlands until 1886, was based on the Enlightenment principle of sentencing criminals proportionately to the crime committed, dismissing the personality of the criminal to avoid arbitrariness. This focus on material evidence is also thought to have contributed to the small role of psychiatrists in court cases. ${ }^{26}$

Liberal and social reformers succeeded in reforming infanticide law only in 1854, when the death penalty was abolished for unmarried women who committed infanticide for the first time and was replaced by a prison sentence of five to ten years. In 1870 the death penalty was abolished for all other cases of child murder. In 1886, when a new Dutch Criminal Law was introduced, the death penalty as such was abolished and more attention was paid to the strong fear experienced by the murdering mother. The law from 1854 explicitly mentioned the unmarried mother's fear of discovery of her pregnancy, and her resulting abnormal psychic and physical condition before and during delivery, as a reason to kill her child. In 1886 this section was broadened to include married women. Importantly, this law stated that, unlike in other crimes, a plea for extenuating circumstances was impossible, since these circumstances had already been assumed in the

21 Jackson, Infanticide, op. cit. (note 2), 13, 123.

22 Faber, 'Vrouwen', op. cit. (note 4), 156-8; Noordam, op. cit. (note 4), 37.

23 J.H. de Hes, Genees-regtskundige verhandeling, over den kindermoord, ten dienste van geneeskundigen en regtsgeleerden [Forensic Treatise on Child Murder, to the Benefit of Physicians and Jurists] (Arnhem: C.A. Thieme, 1824), 191, complained that section 300 of the CP did not mention the 'mental condition of the mother'. ${ }^{24}$ Ermers, op. cit. (note 4), 118.

${ }^{25}$ Harry Oosterhuis and Marijke Gijswijt-Hofstra, Verward van geest en ander ongerief. Psychiatrie en geestelijke gezondheidszorg in Nederland (1870-2005) [Mentally Confused and other Complaints. Psychiatry and Mental Health in the Netherlands (1870-2005)] (Houten: Bohn Stafleu Van Loghum, 2008), 222.

${ }^{26}$ G. Donker and S. Faber, 'De ziekelijke zenuwoverspanning van Jannetje J. Een rapport van F.S. Meijers in een Amsterdamse kindermoordzaak uit 1912' ['The sickly over-excitement of Jannetje J. A report by F.S. Meijers in an Amsterdam case of child murder from 1912'], in Frans Koenraadt (ed.), Ziek of schuldig? Twee eeuwen forensische psychiatrie en psychologie [Ill or Guilty? Two Centuries of Forensic Psychiatry and Psychology] (Arnhem/Amsterdam: Gouda Quint/Rodopi, 1991), 67-83: 67-8. 
specific description of the crime in the law: the section on child murder mentioned 'the execution of a decision made under the influence of fear of the discovery of her upcoming delivery'. This probably contributed to a dismissal of the overall mental condition of the mother. ${ }^{27}$ Since the law already assumed these women's state of bewilderment during delivery, further inquiry as to the cause would be unnecessary. ${ }^{28}$ In addition, the distinction between married and unmarried women was obliterated. The maximum prison sentence for child murder was reduced to six years. ${ }^{29}$ The new Dutch penal code from 1886 furthermore introduced a distinction between murder and manslaughter of children, the difference depending on the moment (before or during the delivery) when the mother had decided to kill her baby. ${ }^{30}$

In contrast to England, where infanticide was mostly prosecuted as murder or manslaughter until 1922, child murder was a separate section in Dutch law and a law punishing the hiding of a pregnancy in and of itself did not exist. The age of the newborn child was, moreover, neither specified in the French Code Pénal nor in the new Dutch laws introduced in the second half of the nineteenth century. These new laws took into account that child murder was a last resort for mostly poor, unmarried mothers and therefore showed awareness of the difficult plight of these women. This new cultural awareness dovetailed with sympathy for prostitutes, who were increasingly regarded as victims of male lust as well. In the Netherlands, Christian politicians and feminists advocated the abolition of the regulation of prostitution, especially in the second half of the nineteenth century and the first decades of the twentieth. ${ }^{31}$ Nevertheless, prostitution and adultery were much more important themes in this political struggle over female sexuality than infanticide.

In the Netherlands so far only one case of infanticide has been found during which psychiatrists were called in as expert witnesses to establish whether the accused had been suffering from insanity, a condition that could potentially exonerate her. This case was tried before an Amsterdam court in 1911. ${ }^{32}$ In general, few Dutch doctors were invited into the courtroom to assess the mental condition of criminals. ${ }^{33}$ In other countries psychiatry began to play a role in court much earlier. In France, for instance, psychiatrists became involved in court cases to establish the accountability of suspects in the 1820 s, coining

27 Ibid.

${ }^{28}$ Alphonse Fernande Ockerse, Kindermoord en kinderdoodslag [Child Murder and Manslaughter] (Nijmegen: H.C.A. Thieme, 1891), 3.

${ }^{29}$ Ermers, op. cit. (note 4), 119-20.

30 Ockerse, op. cit. (note 28), 16.

${ }^{31}$ Petra de Vries, Kuisheid voor mannen, vrijheid voor vrouwen. De reglementering van prostitutie in Nederland, 1850-1911 [Chastity for Men, Liberty for Women. The Regulation of Prostitution in the Netherlands, 1850-1911] (Hilversum: Verloren, 1997).

32 Donker and Faber, op. cit. (note 26), 67-83. Recent research into the archives of the provincial courts of 's-Hertogenbosch has confirmed the lack of the use of psychiatric expertise in cases of infanticide: Michèle Hoekstra, 'Krankzinnige misdaden, krankzinnige vrouwen? Een onderzoek naar het bestaan van theorieën over kraambedpsychosen en het gebruik ervan bij kindermoordzaken van 1886 tot 1920' ['Insane crimes, insane women? A research into theories on mania puerperalis and its use in cases of child murder 1886-1920'] (unpublished MA thesis: Utrecht University, 2012).

33 Oosterhuis and Gijswijt-Hofstra, op.cit. (note 25), 222. Exceptions are also noted by S. von Ruller, 'De territoriumstrijd tussen juristen en psychiaters in de negentiende eeuw' ['The struggle for territory between jurists and psychiatrists in the nineteenth century'], in Frans Koenraadt (ed.), Ziek of Schuldig, 23-33; see also I. Weijers en F. Koenraadt, 'Een eeuw forensische psychiatrie en psychologie in Nederland' ['A century of forensic psychiatry and psychology in the Netherlands'], in F. Koenraadt, C. Kelk and J. Vijselaar (eds), Tussen behandeling en straf. Rechtsbescherming en veiligheid in de twintigste eeuw [Between Treatment and Punishment. Legal Protection and Security in the Twentieth Century] (Deventer: Kluwer, 2007), 1-74. 
the concept of monomania. ${ }^{34}$ Nevertheless, despite many French medical studies on puerperal insanity, it seems that the latter notion was rarely applied in cases of child murder before $1901 .^{35}$ In Germany as well, physicians' expertise was part of legal proceedings from the eighteenth century. ${ }^{36}$ In cases of infanticide, eighteenth-century German doctors sometimes described the mental condition of the mother, but did not use the concept of mania puerperalis, ${ }^{37}$ although German physicians had published on that topic since the seventeenth century. ${ }^{38}$

Subsequently, psychiatrists seem to have played a minor role in Dutch, German and French cases of infanticide. Their lack of involvement stands in sharp contrast to their colleagues in England, however, probably relating to the different legal systems. The adversarial nature of legal proceedings in England, as contrasted with the inquisitorial system in continental law, could explain this difference. ${ }^{39}$ In addition, the Dutch system lacked a jury. Local physicians and professors in medicine were only called in randomly as expert witnesses in court. In contrast to France, there were no court-appointed physicians in the Netherlands. A law from 1838 determined that expert statements were not to be considered as evidence by and of themselves. They could only contribute to the judge's opinion. $^{40}$

Donker and Faber have suggested that the late application of the psychiatric concept of mania puerperalis in the Netherlands was due to the specific formulations of the Dutch laws on infanticide, in combination with the emphasis on material evidence like physical proof and witness statements in the Dutch legal system. However, they have neither done extensive research to back up this suggestion, nor examined the much broader and important role of forensic medicine - as opposed to forensic psychiatry - in cases of infanticide. Specifically, their isolated focus on the mind dismisses in advance

\footnotetext{
34 Jan Goldstein, Console and Classify. The French Psychiatric Profession in the Nineteenth Century (Cambridge: Cambridge University Press, 1987), 152-96.

35 The French law of 1901 explicitly mentioned the morbid state of the mother during delivery: Richard Lalou, 'L'infanticide devant les tribunaux français (1825-1910)' ['Child Murder Before the French Courts (1825-1910)'], Communications, 44 (1986), 175-200: 194, 200. Although scholars have addressed the presence of puerperal insanity in French medical discourse, I have not found many references to its application to law suits; see also Daniela Tinková, 'Protéger ou punir? Les voies de la décrimininalisation de l'infanticide en France et dans le domaine des Habsbourg (XVIIIe-XIXe siècles) ['To Protect or to Punish? The Ways of the Decriminalisation of Infanticide in France and the Habsburg Counties (18th and 19th Centuries)'], Crime, Histoire \& Sociétés, 9, 2 (2005) 43-72; and Dominique Vallaud, 'Le crime d'infanticide et l'indulgence des cours d'assises en France au XIXième siècle' ['The Crime of Infanticide and the Lenience of the Assize Courts in France in the 19th Century'], Social Science Information, 21, 3 (1982), 475-499: 484.

${ }^{36}$ Maren Lorenz, 'Er ließe doch nicht eher nach bis er waß angefangen'. Zu den Anfängen gerichtspsychiatrischer Gutachtung im 18. Jahrhundert' ['He wouldn't let go until he started something.' On the beginning of forensic expertise in the 18th century'], in Erhard Chvojka et al. (eds), Neue Blicke. Historische Anthropologie in der Praxis [New Perspectives. Historical Anthropology in Practice] (Vienna: Böhlau, 1997), 199-222.

${ }^{37}$ Maren Lorenz, Kriminelle Körper - Gestörte Gemüter. Die Normierung des Individuums in Gerichtsmedizin und Psychiatrie der Aufklärung [Criminal Bodies - Criminal Minds. The Normalisation of the Individual in Enlightenment Forensic Medicine and Psychiatry] (Hamburg: Hamburger Edition, 1999), 208-25, 255, 270.

${ }^{38}$ M. Lanczik et al., 'Are Severe Psychiatric Disorders in Childbed of Endogenous or Organic Nature? German Contributions to the Biological, Nosological and Psychopathological Research in Postpartum Psychosis in the 18th and 19th Century', Archives of Women's Mental Health, 9 (2006), 293-9.

${ }^{39}$ In contrast, generally the inquisitorial system is seen as more conducive to the role of forensic doctors than the adversarial system, see Catherine Crawford, 'Legalizing medicine: early modern medicine and the growth of medico-legal knowledge', in Michael Clark and Catherine Crawford (eds), Legal Medicine in History (Cambridge: Cambridge University Press, 1994), 89-116; Watson, op. cit. (note 11), 9-10.

40 This changed in 1926.
} 
more complicated and entangled body-mind constellations. This article, therefore, further explores the cause of the extremely late reference to potential insanity in cases of infanticide, compared to Britain, by analysing textbooks of forensic medicine, medical and legal journals, in addition to court cases. I will describe the relationship between body and mind in court cases of infanticide and argue that the emphasis on material evidence and the particular formulation of Dutch laws on infanticide were indeed grounds for a late application of the concept of mania puerperalis, as Donker and Faber have suggested. In addition I propose to take into account the contemporary cultural and medical discourses on the connections between body and mind, which left enough space to articulate mental confusion without referring to academic psychiatric concepts and thus made the acceptance of new psychiatric knowledge less urgent, thus explaining why this knowledge did not travel to the courtroom.

Therefore in the following paragraphs I explore legal records, medical textbooks and articles in medical and legal journals to see whether the possible causes of the scant Dutch attention to mental aspects in cases of infanticide (a general focus on material evidence in the Code Pénal; no options for partial accountability; and the impossibility of pleas for extenuating circumstances from 1854), as suggested in the secondary literature, can be corroborated. I will argue that all of these factors played a role, but do not suffice to explain the minor significance of states of mind. Equally important are the presence of a vocabulary on emotion, both medical and vernacular, which accorded room to mental aspects. In this particular discourse, body and mind were intertwined.

\section{Puerperal Insanity and Travelling Knowledge}

In order to account for the late entrance of psychiatric expertise to Dutch cases of infanticide, the first question we need to address is whether the concept of mania puerperalis was known in the Netherlands. Whereas French, German and English physicians and psychiatrists developed this notion, sometimes in relation to infanticide, this knowledge did not complete its journey to the Netherlands, as this section will show. Interestingly, the notion was introduced by a Dutch doctor who had read foreign texts describing the concept, but for several reasons it was not regarded as important enough to be used on a regular basis by Dutch physicians or legal scholars. Therefore I will address the boundaries to this travelling concept and its contact zones.

Although medical theories on madness caused by pregnancy and childbirth had circulated since antiquity - mostly seen as caused by the sedimentation of the mother's milk in the brain - the French psychiatrist Jean-Étienne Dominique Esquirol (1772-1840) dismissed the paradigm of humours and began the empirical observation of women's psychoses directly after childbirth. ${ }^{41}$ He located the origins of mental illness in the passions of the soul, rather than in organic causes.

Several German doctors had written on post-partum mania and melancholia from the seventeenth century, viewing them until the beginning of the nineteenth century as intellectual disturbances and regarding the affective components of the psychoses merely as epiphenomena. Until the middle of the nineteenth century, German psychiatrists generally included all forms of post-partum psychosis under the heading of mania

41 Jean-Étienne Esquirol, Des maladies mentales considérées sous les rapports médical, hygiénique et médicolégal [Mental Illness in Relation to Medicine, Hygiene and Forensic Science] (Paris: J.-B. Baillière, 1838). 
puerperarum, including those with melancholic symptoms, not yet distinguishing between insanity and mood disorder. ${ }^{42}$

Nancy Theriot has described how the term puerperal insanity was constructed by nineteenth-century American doctors and patients. Most physicians divided the disease into phases of the reproductive process (pregnancy, lactation, parturition) or into maniacal, melancholic and depressive puerperal insanity. Insanity of parturition or puerperal mania, characterised by maniacal symptoms like an abnormal state of excitement and a hostility to husband or child, was regarded as the most common type of puerperal insanity. Theriot argues the disease was not only a product of male physicians' notions of proper femininity, but also reflected contemporary ideas on the connections between mind and body in mental illness. 'Puerperal insanity can be interpreted as a socially constructed disease, reflecting both the gender constraints of the nineteenth century and the professional battles accompanying medical specialization' ${ }^{43}$

In these French, German and American medical discussions on the aetiology of puerperal insanity, the crime of infanticide hardly played a role. Another French psychiatrist, however, Louis-Victor Marcé, elaborated on the connection between puerperal madness and child murder. Marcé regarded women's reproductive functions as vital causes of mental illness, but also left room for hereditary predispositions and emotional triggers. Focusing mostly on physical causes of the mental instabilities associated with pregnancy and the postpartum period, Marcé suggested that, although more research had to be done into the possible exoneration of the mother accused of infanticide based on her mental conditions, this was certainly an option. ${ }^{44}$

In England, the London obstetrician Dr Robert Gooch produced the first detailed account in English of puerperal insanity, described by Hilary Marland as 'very much a disorder of the nineteenth century' ${ }^{45}$ and from 1822 'puerperal insanity' was used in defence pleas, mediating 'between the wrath provoked by high levels of child murder and the sympathetic approach towards mothers who committed the crime'. ${ }^{46}$ As Daniel Grey has recently shown, the diagnosis remained a frequent feature in Englishwomen's infanticide trials until the first two decades of the twentieth century. ${ }^{47}$ In Ireland, as well, the concept was often put forward in cases of newborn child murder, and the link was made in the medical literature from the second half of the nineteenth century. ${ }^{48}$ However, in America considerable resistance was shown toward the application of this

\footnotetext{
42 Lanczik et al., op. cit. (note 38), 294.

43 Nancy Theriot, 'Diagnosing Unnatural Motherhood: Nineteenth-century Physicians and "Puerperal Insanity", American Studies, 30, 2 (1989), 69-88: 72.

${ }^{44}$ L.-V. Marcé, Traité de la folie des femmes enceintes des nouvelles accouchées et des nourrices et considerations medico-légales qui se rattachent à ce sujet [Treatise on the Madness of Pregnant, Recently Delivered and Breastfeeding Women and Forensic Considerations on the Subject] (Paris: Baillière, 1858); see also Katharina Trede et al., 'Treatise on Insanity in Pregnant, Postpartum, and Lactating Women (1858) by Louis-Victor Marcé: A commentary', Harvard Review of Psychiatry, 17, 2 (2009), 157-65.

45 Hilary Marland, Dangerous Motherhood. Insanity and Childbirth in Victorian Britain (Basingstoke: Palgrave Macmillan, 2004), 3.

46 Ibid., 172; Hilary Marland, 'Getting away with murder? Puerperal insanity, infanticide and the defence plea', in Mark Jackson (ed.), Infanticide. Historical Perspectives on Child Murder and Concealment, 1550-2000 (Aldershot: Ashgate, 2002), 168-92; see also Tony Ward, 'The Sad Subject of Infanticide: Law, Medicine and Child Murder, 1860-1838', Social and Legal Studies, 8, 2 (1999), 163-80.

47 Daniel J.R. Grey, 'Discourses of Infanticide in England, 1880-1922' (unpublished PhD thesis: Roehampton University, 2008), 260-1.

${ }^{48}$ Pauline Prior, Madness and Murder. Gender, Crime and Mental Disorder in Nineteenth-Century Ireland (Dublin: Irish Academic Press, 2008), 126-8.
} 
psychiatric notion to late nineteenth- and early twentieth-century infanticide cases. Janet Galley has suggested three reasons why American doctors, lawyers and the general public rejected the connection between infanticide and female insanity. First, the American system of state-based criminal law implied that there was neither a uniform legal response to infanticide or insanity, nor national studies into the phenomenon. Second, at the end of the nineteenth century, the number of infanticide cases in America decreased due to the creation of foundling homes and homes for unwed mothers, as well as the declining cost of rubber condoms. The lower number of cases led to fewer demands on state legal communities to change the existing laws in relation to the crime of infanticide. Third, many Americans regarded the insanity defence in general as a way for criminals to escape their punishment. American beliefs in free will and the republican ideal of individual responsibility worked against the notion of unaccountability on the basis of mental illness. ${ }^{49}$ These American arguments against the use of the insanity defence in cases of infanticide differed completely from the Dutch ones.

In the Netherlands, mania puerperalis was described in Dutch for the first time by Dr A. Moll in 1822 in a medical journal, summarising the research by Gooch, based on an article in a German journal. ${ }^{50}$ Moll, who wrote the first Dutch textbook of forensic medicine, published in 1825, briefly mentioned mania puerperalis in his chapter on insanity and accountability, classifying it under 'melancholia', but did not refer to the psychological condition of parturient women in the chapter on infanticide, which was limited to the material and physical traces on the bodies of baby and mother. ${ }^{51}$

Therefore, contrary to what other Dutch historians have assumed, ${ }^{52}$ the notion of mania puerperalis or puerperal insanity was introduced in the Netherlands in 1822. Nevertheless, in the medical literature few connections were made with insanity pleas in cases of infanticide. ${ }^{53}$ It would be incorrect, however, to state that forensic doctors did not display any interest in the mental state of the mother in these cases. Although most of the authors of textbooks of forensic medicine did not explicitly mention mania puerperalis, several devoted some lines to the psychic condition of the mother and its relationship to legal accountability. Already at the end of the eighteenth century, the aforementioned Enlightened doctor Petrus Camper referred to the emotions experienced by women during pregnancy and delivery. Whereas pregnancy makes even married women melancholic, Camper noted, unmarried, solitary women, who are despised by the community, experience fear, pain and desperation during delivery, leading 'in that terrible moment of deep emotion' to the killing of their child. ${ }^{54}$

\footnotetext{
49 Janet Galley, 'Infanticide in the American Imagination 1860-1920' (unpublished PhD thesis: Temple University, 2007), 110-15, 283-4.

${ }^{50}$ A. Moll, 'Over de krankzinnigheid (mania) der zwangeren en kraamvrouwen, van dr. Gooch (uittreksel), met daartoe betrekkelijke waarnemingen van dr. Moll' ['On the Insanity (Mania) of Pregnant and Lactating Women, by Dr Gooch (Summary), with Relevant Observations by Dr Moll'], Praktisch Tijdschrift voor de Geneeskunde [Practical Journal for Medicine] (1822), 201-24: 217.

51 A. Moll, Leerboek der gerechtelijke geneeskunde voor genees- en regtskundigen [Textbook of Forensic Medicine for Physicians and Jurists], Vol. I. (Arnhem: D.K. Muller, 1825), 326.

52 Ermers, op. cit. (note 4), 120.

53 Dutch medical dissertations on puerperal psychoses, dating from the late nineteenth century, discussed the aetiology of this condition, mostly focusing on infections contracted during childbirth and critically discussing the hereditary components. They were not interested in the connections with child murder; see S. Tonckens, De mania puerperali [On Puerperal Mania] (Groningen: Wolters, 1847); W.T.M. Weebers, Over puerperaalpsychosen [On Puerperal Psychoses] (Leiden: H. Coebergh, 1893).

${ }^{54}$ Camper, op. cit. (note 16), 7.
} 
Camper's reference to emotions as causing women's disturbance during childbirth was very common in medical and alienist literature and quite easily overlapped with early psychiatric notions. In 1824, for instance, medical doctor J.H. de Hes agreed with Camper's plea for a more humane treatment of 'unhappy mothers' in his treatise on the forensic aspects of child murder. He claimed that, in the Netherlands, 'the advice given by Camper fifty years ago, to give heed to the Psychic condition of the mother, seems to have disappeared'. ${ }^{55}$ De Hes located the cause for this disappearance in the decline of Dutch forensic medicine, especially in comparison with Germany, thus siding with many other doctors who complained about the sorry state of Dutch forensic science during the nineteenth century. Camper was regarded by de Hes as far ahead of his time, applying the 'teachings of Psychic diseases' to the practice of law in a period in which this was still very imperfect. ${ }^{56}$ Referring to Moll and van Eldik's article from $1822,{ }^{57}$ de Hes underlined the existence of melancholia and mania before, during and after childbirth. ${ }^{58}$ He located the cause of puerperal insanity in the genitals, triggered by emotional upheaval. He left open the possibility of these women being prone to the disease by a certain condition of the brain. ${ }^{59}$ Referring to Wigand, de Hes saw the sudden surge of blood to the head, increasing the passions, as prompting madness. ${ }^{60}$ It was the task of the forensic physician to find out if violence committed to a child had been performed in a state of melancholia or mania. ${ }^{61}$ De Hes, then, was one of the few forensic doctors who explicitly advocated attention to the mind of the mother. He regarded this focus, however, as in line with older notions of emotional upheaval, indicating how the 'new' psychiatric discourse fused with an already existing discourse on emotions.

Thus the notion of puerperal mania travelled to the Netherlands from France, Germany and England. Although it was taken up by Moll and de Hes, several factors might have contributed to halting this notion from further travel to the courtroom. First, it was not always directly connected to infanticide. Second, it overlapped to an important extent with an older vocabulary of emotion, thus making its application less urgent, as I will explain below. Third, a contemporary, omnipresent notion of the inadequacy of Dutch forensic medicine might also account for the lack of interest in the application of new research to forensic medicine.

Moreover, another explanatory factor might have been the disagreement over the mania women possibly suffered in regard to childbirth. Legal scholar De Feyfer in his dissertation Treatise on Child Murder (1866) pointed to the lack of agreement between scholars in regard to the temporary insanity of child murderesses during and after birth. Still, he admitted that unmarried women, who often had a very quick delivery because of their vehement emotions, could easily attain a state of mental confusion. Thus far, forensic doctors had not paid enough attention to the psychic condition of the mother, according to de Feyfer, having focused too much on the material facts, whereas there was every reason to regard them as not fully accountable for their actions. Heeding the 'tight connection

\footnotetext{
55 J.H. de Hes, Genees-regtskundige verhandeling, over den kindermoord, ten dienste van geneeskundigen en regtsgeleerden [Forensic Treatise on Child Murder, for Physicians and Jurists] (Arnhem: C.A. Thieme, 1824). 56 Ibid., 159.

${ }^{57}$ Van Eldik was the co-editor of the journal (with Moll) but does not seem to have been the co-author of the article.

58 De Hes, op. cit. (note 55), 175.

${ }^{59}$ De Hes, op. cit. (note 55), 178.

${ }^{60}$ De Hes, op. cit. (note 55), 184-5.

${ }^{61}$ De Hes, op. cit. (note 55), 187.
} 
between soul and body in human beings', these women's physical sufferings caused a limitation of the rational mind. ${ }^{62}$ In de Feyfer's text, the connection between body and mind was central, emotions being inextricably connected to the psyche. Moreover, he confirmed the neglect by Dutch forensic doctors of the mental condition of criminal mothers, pointing to the material aspects of Dutch law. This claim was underlined by Dr W. Koster, who also concluded in his textbook of forensic medicine from 1877 that, in most cases, the forensic doctor only had to unveil the facts relevant to finding whether the baby was violently killed, without mentioning the psychic state of the mother. ${ }^{63}$

The disagreement over the notion of mania puerperalis continued into the early twentieth century. Whereas during the first half of the nineteenth century, doctors were mostly concerned with classifying puerperal insanity and discussed its existence in general, during the second half of the nineteenth century they debated whether post-partum madness could serve to claim diminished legal responsibility. As I have shown above, the French psychiatrist Marcé was the first to suggest that puerperal insanity could actually function as such. However, the famous French forensic doctor Tardieu disagreed with him in a text written in 1868. Both Tardieu and, in 1897, pathologist and forensic scholar Paul Brouardel doubted the existence of acute insanity during and directly after childbirth. ${ }^{64}$ In their Textbook of Forensic Obstetrics (1908), the Dutch doctor Hector Treub and the legal scholar A. Tak refuted the opinions of these French scholars. Treub and Tak, referring to Austrian-German psychiatrist Richard von Krafft-Ebing's studies on consciousness and mania, regarded attacks of 'mania transitoria' in parturient and recently delivered women and 'transitory deliria on an epileptic and hysterical basis' as potential grounds for nonaccountability. ${ }^{65}$ A few years earlier, Dr P.H. Simon Thomas had argued in the Dutch Journal for Criminal Law that the emphasis on fear in the 1886 Dutch law on infanticide, and the description of 'special affects' in the accompanying explanatory memorandum, did not imply a reference to a psychic condition that made women unaccountable for their actions. He added that real mania during childbirth was rare and hard to prove. ${ }^{66}$ Thus medical and legal opinions on the existence of puerperal insanity, as well as its relationship to unaccountability, continued to differ at the beginning of the twentieth century.

To summarise, we have seen that knowledge of the concept of mania puerperalis existed in the Netherlands, introduced by Moll. Fleeting references in Dutch medical journals, ${ }^{67}$ as well as a limited number of allusions in other texts on forensic medicine, indicate an awareness of the condition. However, several barriers served to keep this knowledge from being generally accepted and used in court cases. Physicians continued to doubt the existence of this form of mania. Moreover, it was not always directly connected to infanticide. Furthermore, the law was interpreted in different ways. Some regarded the mentioning of fear in the law itself as a reason not to look for further evidence of psychic

62 D. de Feyfer, Verhandeling over den kindermoord [Treatise on Child Murder] (Utrecht: Kemink en zoon, 1866), 204-10.

63 Dr W. Koster, Leerboek der gerechtelijke geneeskunde voor artsen en rechtsgeleerden [Textbook on Forensic Medicine for Doctors and Jurists] (based on the German textbook by Dr E. Buchner) (Tiel: H.C.A. Campagne, 1877), 358.

${ }^{64}$ A. Tardieu, Etude médico-légale sur l'infanticide [Forensic Study on Infanticide] (Paris: Baillière, 1868), 226-40; P. Brouardel, L'Infanticide [Infanticide] (Paris: Baillière, 1897), 164.

${ }^{65}$ Dr Hector Treub and Mr A. Tak, Leerboek der gerechtelijke verloskunde [Textbook of Forensic Medicine] (Haarlem: De erven F. Bohn, 1908), 211-7.

${ }^{66}$ Dr P.H. Simon Thomas, 'Kinderdoodslag en kindermoord' ['Manslaughter of Children and Child Murder'], Tijdschrift voor Strafrecht [Journal for Criminal Law], 15 (1903), 74-7.

${ }^{67}$ Geneeskundige Courant [Medical Newspaper], 16, 3 (1862) and 56, 10 (1902). 
illness. Others pointed to the general emphasis on material evidence in the Dutch law. Last, it seems that the discussion of emotions in relation to infanticide left considerable room to include psychic components. For example, in an article in a Dutch medical journal, the anonymous authors vaguely referred to 'new research into anthropology and psychology' to argue that the term 'new born' in the law should be abolished. This adjective was intended to leave space for a lenient sentence for the mother, since

the unmarried mother, directly after birth, and after the recently suffered labour pains, has not yet felt full love for the new-born baby, and the birth itself so powerfully impacts on the body and mind of the woman, to be able to assume, that the murder committed immediately after birth was committed in a sickly and psychically excited condition.

Since, according to the authors, this phase of physical and psychic confusion could not be pinned down to an exact time frame, the term 'new born' should be obliterated from the law. Importantly, the authors use the term 'abnormal somatic condition', referring to the interconnection of body and mind. ${ }^{68}$ I shall explore this relationship between body, mind and affect further by looking at the role of forensic doctors in Dutch court cases of infanticide in order to account for the barriers that prevented psychiatric expertise from travelling to the courtroom, in contrast to medical expertise on the body of the child, which did find its way to court.

\section{Court Cases of Infanticide}

Physicians played an important role in cases of infanticide. In nearly every instance, doctors were called in to inspect the body of the dead baby, to establish whether it had been born alive. They assessed whether it was full term, and they searched for signs of violence. An autopsy was also performed to show the condition of the inner organs, especially of the lungs, and included the findings of the infamous lung test. This test, invented at the end of the seventeenth century, consisted of placing the lungs in a bucket of water in order to see whether they sank or floated. Floating lungs were thought to indicate the presence of oxygen, hence pointing to a live birth. This lung test was heavily debated amongst doctors and legal scholars. It was considered to be faulty, especially since the lungs could contain gas that was often present in corpses, which could also make them float. Throughout the eighteenth and nineteenth centuries, physicians studied more accurate lung tests and other signs to use in addition to the test. Nevertheless, it continued to be used, although only as one part of increasingly extensive post-mortem reports. ${ }^{69}$

In all the cases consulted for which sufficient documentation has been preserved, the lung test was executed and, in all of these - except for one where the results were inconclusive - it was concluded that the baby had been born alive. This evidence was not sufficient for a conviction, however. The doctors were also requested to indicate potential causes of death. They often suggested suffocation or bleeding, with differing degrees of certainty. It then depended on the confession of the accused, witness statements and other material evidence whether the judge would convict the mother. In eighteen out of fiftyseven cases, she was acquitted. It is, however, difficult to reconstruct the exact weight of the forensic evidence.

Especially in cases dating from the first half of the nineteenth century, judges and lawyers often approached forensic evidence critically. In a case from 1839 , for instance, a

68 Geneeskundige Courant, 9, 48 (1855).

${ }^{69}$ See Mark Jackson, 'Suspicious infant deaths: the statute of 1624 and medical evidence at coroners' inquests', in Clark and Crawford, op. cit. (note 18), 64-86. 
judge criticised the results of a lung test, indicating that the child, having respired, had been born alive and strangled by the umbilical cord. He argued that a child could have breathed before and during birth, yet still be born dead. Since neither these signs, nor the other evidence, provided enough certainty, the accused was acquitted. ${ }^{70}$ Similarly, in a case from 1852 the judge deliberated that the lung test was considered an 'insecure instrument' in forensic science and famous medical doctors differed in their opinions. He acquitted the accused. ${ }^{71}$ One explanation for the qualms expressed by judges in regard to the lung test might be that they were reluctant to sentence women accused of infanticide to death, a dilemma they no longer faced in the second half of the nineteenth century. In addition, as the visum repertum (autopsy report) became more extensive, the lung test decreased in importance, as other bodily evidence was increasingly taken into account. Still, until the beginning of the twentieth century lawyers for the defence would invite professors of medicine to court to underscore the uncertainty of the lung test. ${ }^{72}$

The different values attached to the lung test by people in different locations with differing interests points to the shape that knowledge might take while travelling to other places. Whereas in medicine, as evidenced by textbooks of forensic medicine, the lung test could be promoted wholeheartedly or with some reserve, in the courtroom different criteria applied. For example, in a case from 1845 the defence called in a professor of medicine and a medical doctor as additional witnesses, who claimed the lung test only presumed that breathing took place, and that there were examples of breathing and life before birth. ${ }^{73}$ Similarly, in a case from 1857 the defence lawyer included professor of medicine van Geuns, who was critical of the premises of the medical report. That the child had been mature and breathing at birth could be concluded from the report 'with some measure of probability', but not as 'strong evidence'. The judge admitted that the medical report had not provided 'undisputed certainty', but 'a high degree of probability' was enough to give Reinou Vette, a thirty-four-year-old female worker, the death penalty. ${ }^{74}$ Thus forensic doctors appointed by the authorities often claimed certainty in regard to the results of the lung test, but when this knowledge travelled to the courtroom the judge or the medical experts hired by the defence transformed this into probability or a lack of certainty.

Disagreement amongst the several experts involved in the investigation and court case could cause severe problems. In a case from 1822 the defence's request for more experts was rejected by the judge, since that would give the impression that

the report had been subjected to the judgement of other experts, which would be little respectful to the experts appointed by the judges, and which will make it impossible to find experts in future, which is already difficult now. To question further experts, professors against professors... cannot be advantageous for the interests of Justice. ${ }^{75}$

Equally, in texts on forensic medicine authors were concerned with the image of forensic medicine if several doctors disagreed with each other in public court cases. Obstetrician W.G. ten Houte de Lange complained that forensic medicine in Holland was a 'disgrace

\footnotetext{
${ }^{70}$ Noord-Hollands Archief (hereafter NHA), Archief Criminele Rechtbank, inv. no. 139 (case of Diewertje Boonacker, 1839).

${ }^{71}$ NHA, Provinciaal Gerechtshof Noord-Holland (hereafter PGNH), inv. no. 45 (case of Margaretha Pynacker, 1852).

72 NHA, PGNH, inv. no. 4 (case of Antje Roest, 1845); GA, inv. no. 289 (case of Guurtje Brederode, 1909).

73 NHA, PGNH, inv. no. 4 (case of Antje Roest, 1845).

${ }^{74}$ NHA, PGNH, inv. no. 50 and 280 (case of Reinou Vette, 1857).

75 NHA, HvA, inv. no. 276 (case of Neeltje Janssen), 1822.
} 
for science', a 'plaything for the cleverness of jurists'. ${ }^{76}$ In a case dating from 1884 , the accused was acquitted because the three experts interrogated at the trial contradicted the findings of the post-mortem performed by two other doctors, even though she had made a confession: she had put her fingers in the mouth and throat of the baby, but the experts disagreed over whether that had actually caused the death or whether the child had died because of problems experienced during birth. The court eventually ruled that, because of the great differences in expert opinion, the guilt of the accused had not been sufficiently proved. ${ }^{77}$ In a similar case, the doctors disagreed over the cause of death (bleeding or suffocation) and therefore it could not be proved that the mother had murdered her baby by pulling a string attached to the baby's neck. ${ }^{78}$ Here as well, difference of opinion directly caused acquittal.

Paradoxically, although medical expertise was considered a vital element of the evidence sought in cases of infanticide, it was not accepted uncritically by judges, especially in the first half of the nineteenth century, possibly to avoid sentencing the accused women to death. Generally, however, in the second half of the nineteenth century, the court agreed with expert opinion when it came to bodily and material evidence. The important role of the forensic doctor in regard to the examination of bodies contrasts with the lack of expertise sought in the realm of the mind.

\section{Expert Opinion and Affect}

The absence of forensic psychiatrists and their scientific vocabulary, however, does not imply reference to the mind was completely absent. To express the state of mind of the accused during or directly after delivery, as well as her accountability, the vocabulary of emotion was appropriated. Terms like 'unconscious' or 'fully sane' were contrasted with 'confusion' or a baffled emotional state. However, the language of affect could probe more deeply into the mind, as evidenced by expressions like 'bewilderment of affect' ('verbijsterde gemoedsaandoening'), ${ }^{79}$ 'fears in movements of the soul' ('angsten in zielsontroering'), ${ }^{80}$ 'utterly moved, desperate, and sufficiently devoid of senses' ('geheel ontroerd, wanhoopend en genoegzaam zinnenloos'). ${ }^{81}$

These emotions, sometimes bordering on madness, hardly ever needed professional affirmation. When, for instance, in 1882 twenty-one-year-old servant Elisabeth Kelder told the court that, during the delivery, her heart had felt like stone and she herself had felt 'mad like a crazy person', the records do not evidence any response by the judge and a medical expert was not called in. ${ }^{82}$ Similarly, in 1885 twenty-two-year-old servant Jantje van Tuil described her condition during her delivery as 'nearly bordering on madness', preventing her from thinking. Subsequently, her neighbours and colleagues were interrogated to confirm her desperation. They underlined her rational behaviour, leading the court to hold the defendant accountable for her crime. ${ }^{83}$ Apparently, no professional expertise was needed.

\footnotetext{
${ }^{76}$ W.G. ten Houte de Lange, Wetenschappelijke bedenkingen tegen de brochure: De ger. gen. gronden ter vrijspraak van D.B. beschuldigde van kindermoord [Scientific Arguments Against the Pamphlet: The Forensic Reasons for the Acquittal of D.B. Accused of Child Murder] (Alkmaar: Herm. Coster, 1842), preface.

${ }^{77}$ NHA, Gerechtshof Amsterdam (hereafter GA), inv. no. 20 (case of Geertruida de Jonge, 1884).

78 NHA, GA, inv. no. 10 (case of Rika de Groot, 1885).

${ }^{79}$ NHA, HvA, inv. no. 454 (case of Grietje Schoenmaker, 1830).

${ }^{80}$ NHA, HvA, inv. no. 454 (case of Grietje Schoenmaker, 1830).

81 NHA, HvA, inv. no. 497 (case of Maria van Dam, 1833).

${ }^{82}$ NHA, GA, inv. no. 56 (case of Elisabeth Kelder, 1882).

${ }^{83}$ NHA, GA, inv. no. 10 and 85 (case of Jantje van Tuil, 1885).
} 
Reference to affect served to account for both corporeal and mental conditions. These could refer to a state of consciousness, and hence to potential responsibility and accountability. In the following case, dating from 1888, this allusion to affect comes clearly to the fore: twenty-four-year-old servant Helena van Krenk at first claimed not to remember whether she had pinched her baby in the neck before or after its death. Neither could she recall if the umbilical cord was torn before or after the child had suffocated. Several physicians were asked whether her amnesia was plausible. Dr Moll claimed that Helena had committed her crime in full consciousness. Dr Doorenbos testified that women often forgot what had happened during a delivery. Dr Luchtmans stated that women in the circumstances experienced by the accused were not generally in a normal condition. However, in his opinion this also depended on the individual, since 'one person gets "into affect" more easily than others'. Since he had neither observed the suspect before, nor after the birth, he had never seen her 'in affect'. He had the impression she had a calm character. ${ }^{84}$ The term 'in affect' was not a conventional medical term and here equated emotion, consciousness and memory. It sufficed to describe the accused's mental condition. The lower court first exonerated her from child murder, since premeditation had not been proved. She was convicted of manslaughter and sentenced to a prison sentence of one year and five months. The court of appeal, however, ruled that the killing of her child had been premeditated and convicted her of infanticide, with a prison sentence of two years and six months. Thus eventually the medical evidence on the accused's mental condition did not contribute to her acquittal.

Expert opinion could, however, endorse exoneration in regard to the speed of birth, corroborating women's claims. Many women testified in court that their babies 'had escaped them' during birth and had fallen on the floor or in the lavatory, causing their deaths. In several cases physicians confirmed the possibility of such deliveries. Interestingly, forensic doctors connected body and mind in their explanation of fast deliveries, as in the case of Maria van Dam, a thirty-three-year-old servant accused of infanticide:

the inconsistency in her answers [during interrogation WR] testifies to the desperation of the prisoner both before, during and after the delivery, causing her to be unable to notice the events and to give a full testimony of them [...] the emotions of a girl surprised by labour can be deregulated by fear so badly that she is hardly conscious of all that is happening, and cannot clearly represent them; also, these affects influence these parts used during labour - this fear especially works on the functioning of the womb - which might cause convulsions of the womb, possibly triggering a faster delivery. ${ }^{85}$

Importantly, this reference to the mind is very much connected to the body and used to explain the fast and sudden delivery, rather than the motive of the accused and her possible unsound mind and lack of responsibility for her actions. ${ }^{86}$

The sheer importance of the discourse on affect is shown in the terms used during the trial of Jannetje Jurgens, the first case in the Netherlands where psychiatrists asserted that the female perpetrator probably suffered from a mental condition while committing child murder. The term mania puerperalis was not specifically mentioned. Dr Herman Schoo, who was one of the two physicians who conducted the autopsy, but was also asked for his opinion on the mental state of the suspect, stated that in his opinion the suspect had committed the crime in a 'fear psychosis'. The other expert, Dr Jacob Voorhoeve,

${ }^{84}$ NHA, GA, inv. no. 122 (case of Helena van Krenk, 1888).

85 NHA, HvA, inv. no. 497 (1833). Also see GA, inv. no. 45 (case of Antje Snieder, 1880).

86 The same argument is put forward by Ten Houte de Lange, op. cit. (note 76), 42. 
suggested that the accused might not have known what she was doing, 'that is, did not commit the crime in full consciousness'. Physician Dr Frederik Meijers wrote in his report on the mental state of Jannetje that she was suffering from 'acute nervous oedema, indicated by her thick, swollen tongue'. Meijers described how the fear of her pregnancy being discovered led to a 'state of sickly excitement of the nerves, which decreases her accountability to a minimum, but cannot be thought to be completely absent'. Dr Schoo agreed with him during the appeal and added that, although he had spoken of 'fear psychosis' during the first trial, he had meant a sickly excitement of the nerves, the wording used by Meijers in his report. Both experts furthermore stated that the fact that Jannetje had hardly felt any pain during the delivery pointed to her pathological excitement of the nerves, the lack of feeling being one of the symptoms of this nervous condition. Severe fear could suppress pain. ${ }^{87}$ Clearly, the physical experience of pain during delivery was directly connected to the woman's mental condition. The language of emotions accorded enough room for mental illness. This should not surprise us, considering that from the early days of psychiatry - for instance, in the description of monomania - the status of the passions or affections had been unclear and the difference between normal and pathological passions was not specified. ${ }^{88}$ Thus a considerable overlap between the language of psychiatry and the more common language of affect remained. This language could, but did not always, explain the particular mental and physical condition of the female suspect and exonerate her. The strong focus of the Dutch law on material evidence, however, meant that the state of mind of the accused was hardly ever the sole focus of the interrogation and therefore rarely served as the only line of defence.

\section{Conclusion}

This article aimed to provide new source material to study the absence of psychiatric expertise in Dutch cases of infanticide, and to explore the use of the concept of 'travelling knowledge' as an approach to the history of forensic medicine. Travelling knowledge might refer literally to medical knowledge and its potential application in the field of law, being received and dispersed in a different country. In the case of mania puerperalis, the Dutch doctor Moll introduced it into the Netherlands by referring to the work of the English doctor Gooch, having read about it in a German journal. More interestingly, however, travelling knowledge can point to the fields of medicine and law as contact zones inviting, promoting or barring the transmission of knowledge. In the Netherlands, the concept of mania puerperalis was not applied to actual court cases of infanticide for several reasons. First, physicians and legal scholars continued to doubt the existence of this form of mania. Moreover, it was not always directly connected to infanticide. Also, the specific formulation of the law strongly determined what medical evidence was needed in court cases. Not only did the Code Pénal generally emphasise material evidence, the laws on infanticide specifically mentioned fear and therefore additional reference to a mental condition of the accused was not needed. Most importantly, I argue, the existing vocabulary on emotion, both vernacular and medical, allowed for an analysis of psychic components, connecting body and mind in the description of the mental state of the mother during and after birth, as well as of the rapidity of her delivery. To conclude, specific national formulations of the law might have been the biggest barrier to the application of psychiatric knowledge, while the presence of an older, useful vocabulary of affect might have been a more hidden obstacle to the introduction of new mental concepts.

${ }^{87}$ NHA, GA, inv. nos 96 and 312 (case of Jannetje Jurgens, 1912).

${ }^{88}$ Goldstein, op. cit. (note 34) 177; see also Lorenz, 'Er ließe', op. cit. (note 36), 207, 220. 